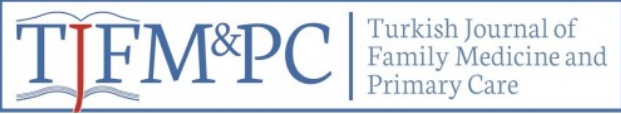

\title{
Determination of The Relationship Between External Pelvic Measurements and Body Mass Index in Young Adults
}

\author{
Genç Erişkinlerde Dış Pelvik Ölçümler ile Beden Kitle İndeksi Arasındaki \\ İlişkinin Belirlenmesi
}

Şükriye Deniz Mutluay ${ }^{1}$, Emine Demir ${ }^{* 2}$

\begin{abstract}
Objective: This study was conducted to evaluate the relationship between pelvic measurements and body mass index (BMI) among pre-pregnancy young adult women in our population. Method: The sample group consisted of 83 midwifery students who agreed to participate in the study. The anthropometric pelvic measurements which are intercrestal diameter (IC), interspinous diameter (IS), intertrochanteric diameter (IT), intertuberous diameter (ITb), and Baudelocque diameter (anteroposterior diameter) was obtained by a single investigator with a pelvimeter. The program Statistical Package for Social Sciences (version 21.0) was used to create a descriptive analysis, and the Pearson correlation coefficient was performed to determine significance $(\mathrm{p}<0.05)$. Results: The participants' mean age was 19.72 \pm 1.16 . The mean values of BMI, IC, IS, IT, ITb and Baudelocque diameter of participants were 22.71 \pm 3.26 , $27.88 \pm 1.74,25.31 \pm 2.01,32.54 \pm 2.23,12.41 \pm 1.51$, and $20.40 \pm 1.62$, respectively. Significant positive correlations were found between IC and BMI (r=0.434), IS and BMI ( $\mathrm{r}=0.285)$, IT and BMI $(\mathrm{r}=0.051)$, and Baudelocque diameter and BMI $(\mathrm{r}=0.502)$. No significant differences were found between ITb and BMI $(\mathrm{r}=0.051$ and $\mathrm{p}>0.05)$. Conclusion: The data indicates that IC, IS, IT, and Baudelocque diameter all correlate with BMI.
\end{abstract}

Key words: Anthropometry, morphology, pelvic measurements, body mass index, midwifery

\section{ÖZET}

Amaç: Bu çalışma, popülasyonumuzda yer alan gebelik dönemdeki öncesi genç erişkin kadınlarda pelvik ölçümler ile beden kitle indeksi (BKİ) arasındaki ilişkiyi değerlendirmek amacıyla yapıldı. Yöntem: Araştırmanın örneklemini, çalışmaya katılmayı kabul eden 83 ebelik öğrencisi oluşturmuştur. Intercrestal diameter (IC), interspinous diameter (IS), intertrochanteric diameter (IT), intertuberous diameter (ITb), ve Baudelocque diameter (anteroposterior diameter) olan antropometrik pelvik ölçümler, tek bir araştırmacı tarafından bir pelvimetre ile elde edildi. Tanımlayıcı bir analiz oluşturmak için Statistical Package for Social Sciences (version 21.0) programı kullanıldı ve anlamlılı̆̆ belirlemek için Pearson korelasyon testi uygulandı (p<0.05). Bulgular: Katılımcıların yaş ortalaması 19.72 \pm 1.16 'dır. Katılımcıların BMI, IC, IS, IT, ITb ve Baudelocque ortalama değerleri sırasıyla 22.71 $\pm 3.26,27.88 \pm 1.74,25.31 \pm 2.01,32.54 \pm 2.23$, $12.41 \pm 1.51$, ve $20.40 \pm 1.62$ 'dir. IC ve BKİ $(\mathrm{r}=0.434)$, IS ve BKİ $(\mathrm{r}=0.285)$, IT ve $\mathrm{BKI}(\mathrm{r}=0.051)$ ve Baudelocque ile $\mathrm{BKI}(\mathrm{r}=0.502)$ arasında anlamlı pozitif korelasyon olduğu tespit edilmiştir. ITb ve BKİ arasında anlamlı fark bulunmamıştır ( $r=0.051$ ve $p>0.05)$. Sonuç: Veriler IC, IS, IT ve Baudelocque çaplarının BMI ile ilişkili olduğunu göstermektedir.

Anahtar Kelimeler: Antropometri, morfoloji, pelvik ölçümler, beden kitle indeksi, ebelik

Received / Geliş tarihi: 18.04.2020, Accepted / Kabul tarihi: 13.07.2020

${ }^{1}$ Cukurova University Faculty of Health Sciences, Department of Midwifery, Adana-TURKEY.

${ }^{2}$ Ege University Faculty of Health Sciences, Department of Midwifery, Izmir-TURKEY.

"Address for Correspondence / Yazışma Adresi: Emine DEMIR, Ege University Faculty of Health Sciences, Department of Midwifery, Izmir-TURKEY.

E-mail: demiremine0146@gmail.com

Mutluay ŞD, Demir E. Determination of The Relationship Between External Pelvic Measurements and Body Mass Index in Young Adults. TJFMPC, 2020;14(3): XX-XX.

DOI: 


\section{INTRODUCTION}

The pelvis is a large bony structure consisting of the os coxae, sacrum, and coccyx; it plays an important role in locomotion, labor, and in the protection of internal genital organs. ${ }^{1-3}$ Pelvis morphology is affected by genetic, environmental, and cultural factors. ${ }^{4-7}$ For example, morphologically, European American women, as compared to African American women, have been found to have a wider pelvic inlet and outlet. Environmentally, the pelvises of people who live in colder climates have wider bone structures in order to reduce heat loss, while the pelvises of people living in tropical regions tend to be narrow in order to reduce heat stress. Women who undergo severe physical activity during their adolescent period are more likely to develop an android pelvis, known as the male-type pelvis. Women who undergo late menarche tend to have larger pelvic structures than women who undergo early menarche. ${ }^{5}$ In addition, women who have been exposed to malnutrition during childhood tend to have smaller pelvic structures. $^{7}$

Although the development of bones in other parts of the body ends at the age of twenty, pelvic bone development lasts up to the age of thirty. ${ }^{5-6}$ In recent years, rapid industrial development has resulted in significant changes in human structural characteristics due to higher standards of living, increased immunization rates, and improved and more accessible health services. Pelvic bone development, which in humans is continuing to evolve over time, is one characteristic affected by these changes. In a study conducted over the past 25 years (1985-2009) in Croatia, in which changes in the characteristic structures (IC, IT, etc.) of pregnant women's pelvic sizes were measured, results showed that the pelvis sizes of the individuals remained constant from 1985-1986 to 1992-1994, but increased after 1992-1994. It is believed that this change was due to difficulties with accessing stress, malnutrition, and health care services during the Battle of the Homeland, which took place in Croatia between 1991 and 1995. ${ }^{4}$

Most studies on pelvis morphology are based on sophisticated methods that include clinical pelvimetry, ultrasonography, computerized tomography scanning, magnetic resonance imaging, and X-ray pelvimetry. However, these methods are not preferred because they are expensive and either poorly predictive or likely to be harmful during pregnancy. ${ }^{8-9}$ Apart from these methods, stature length is a simple commonly used parameter for predicting the normal size of the pelvis, although stature length is a limited predictor. ${ }^{9-14}$ Other than height, interspinous (IS), intercrestal (IC), anterior-posterior diameter (Baudelocque) and intertrochanteric (IT) distances have been used obstetrically for centuries to determine the shape of the pelvis and its transverse capacity; these anthropometric parameters can be very useful when indirectly measuring the size of the birth canal. An external pelvimeter can be used to evaluate these parameters. Pelvic external measurements include the distances between the outer bone sections of the pelvic cavity. These diameters can be measured externally from the pelvis cavity using an instrument called an external pelvimeter. Intertrochanteric, interspinous, intercrestal, and Baudelocque distances can be used to determine the pelvic shape and transverse capacity.

The correlation values obtained in this study were compared with correlation values obtained in earlier studies of pregnant populations that are at risk of cephalopelvic disproportion, as well as a normal delivery group. Even prior to conception, a woman's height, weight, and body structure are important for assuring maternal-fetal health during pregnancy, childbirth, and the postpartum period. It is therefore important to have information about the anthropometric measurements of young adult women, especially those living in low-income countries, because millions of women of fertile age live in these areas, often in adverse environmental conditions, and they frequently have poor nutritional habits or are overweight. ${ }^{12,15}$

Knowing the pelvis morphology is very important in obstetrical cases. Determining the shape of the pelvis and its transverse capacity with anthropometric parameters are very useful when indirectly measuring the size of the birth canal. An external pelvimeter can be used to evaluate these parameters. The external pelvimeter was, in fact, the first method used to evaluate pelvis morphology. ${ }^{4,12,14}$ However, few anthropometric studies concerning pelvic diameters in young people who have not given birth exist. For this reason, this study was conducted to determine reference anthropometric data, and to evaluate the relationship between pelvic measurements and BMI in pre-pregnancy young adult women.

\section{METHODS}

The study group consisted of a total of 83 women, all of whom were first-year midwifery students at Çukurova University, School of Health Science, during 2017-2018. All of them were aged 18-25 years. For this study, the required permissions were obtained from the Ethics Committee of the Çukurova University Faculty of Medicine. In gathering the data, oral consent from the students was taken before the measurements. The students who participated in the study were selected randomly. Students who had a BMI of $>30 \mathrm{~kg} / \mathrm{m}^{2}$, 
bone disease or height less than $1.50 \mathrm{~m}$, or who had given birth to at least one child were excluded from the study. Morphometric measurements of the pelvis were obtained with an external pelvimeter. For measurements, a room with a bed was prepared and the privacy of the participants was assured. Each participant's weight was measured on a sensitive scale while barefoot, and height measurement was taken using a height gauge while the participant was barefoot in the vertical position. Measurements were repeated three times by a single investigator and the arithmetic mean value was taken. The following morphometric measurements of the pelvis were taken with an external pelvimeter when the participant was in an upright position:

Baudelocque diameter (anteroposterior /external conjugate): the distance from the symphysis pubis to the posterior upper part of the sacrum (Fig. 1)

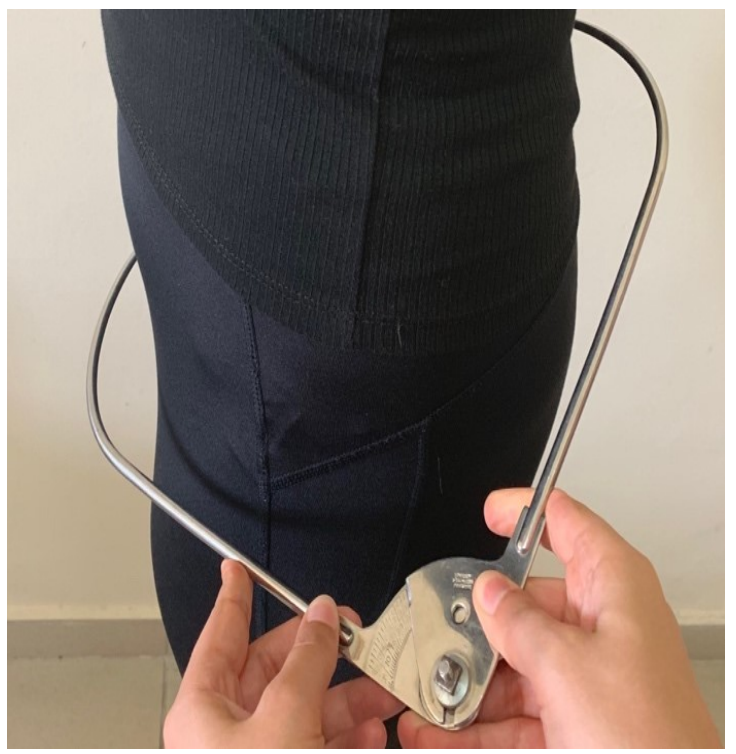

Figure 1.External anteroposterior conjugate (Baudelocque diameter)

Intercrestal diameter (IC): the highest points between both sides of the crista iliaca Interspinous diameter (IS): the distance between anterior superior iliac spines

Intertrochanteric diameter (IT): the distance between femoral trochanters (Fig. 2)

The following measurement was taken with the pelvimeter while the participant was in the dorsal recumbent position on the bed

Intertuberous diameter (ITb): the distance between the bony points of the ischial tuberosities (Fig.2)



Figure 2. External intercrestal (IC), interspinous (IS), intertrochanteric (IT), and intertuberous (ITb) transverse pelvic diameters ${ }^{12}$

BMI is a value obtained by dividing body weight $(\mathrm{kg})$ by height $(\mathrm{m})$ squared $\left(\mathrm{BMI}=\mathrm{kg} / \mathrm{m}^{2}\right)$. BMI does not provide information on a body's weight distribution or the distribution of fat in the body. According to the World Health Organization (WHO), a BMI of $18.5-24.9 \mathrm{~kg} / \mathrm{m}^{2}$ is classified as an optimal range, while BMI values of 25 to 29.9 $\mathrm{kg} / \mathrm{m}^{2}$ are classified as overweight, and BMI values of $\geq 30 \mathrm{~kg} / \mathrm{m}^{2}$ are defined as obese. A BMI of $<18.50 \mathrm{~kg} / \mathrm{m}^{2}$ is classified as underweight. In our study, the BMI values of the participants were defined in an optimal range according to WHO: $22.71 \pm 3.26 \mathrm{~kg} / \mathrm{m}^{2}$.

The SPSS 21 package program was used for the statistical analysis of the data. Descriptive statistics were completed and mean, standard deviation, and minimum-maximum values were taken. To examine the interaction between anthropometric measurements and weight, height, and BMI, Pearson's correlation coefficient was performed and $\mathrm{p}$-values were taken as significant if $\mathrm{p}<0.05$.

\section{RESULTS}

Descriptive studies of individual physical characteristics and anthropometric measurements of the participants are represented in Table 1. Mean $( \pm \mathrm{SD})$ age of the study sample were $19.72( \pm 1.16)$. 


\begin{tabular}{lll|}
\hline $\begin{array}{l}\text { Table 1. Descriptive Studies of Individual Physical Characteristics and Anthropometric Measurements } \\
\text { of Participants }\end{array}$ \\
\hline $\mathrm{n}=83$ & Mean $\pm \mathrm{SD}$ & Min-Max \\
\hline Age (year) & $19.72 \pm 1.16$ & $(18-25)$ \\
Menarche Age (year) & $13.08 \pm 1.33$ & $(9-19)$ \\
Height $(\mathrm{cm})$ & $1.630 \pm 0,06$ & $(1.50-1.80)$ \\
Weight $(\mathrm{kg})$ & $60.61 \pm 9.29$ & $(43-85.5)$ \\
Body Mass Index $\left(\mathrm{kg} / \mathrm{m}^{2}\right)$ & $22.71 \pm 3.26$ & $(19-30)$ \\
Intercrestal diameter $(\mathrm{cm})$ & $27.88 \pm 1.74$ & $(23-33)$ \\
Interspinous diameter $(\mathrm{cm})$ & $25.31 \pm 2.01$ & $(21-32)$ \\
Intertrochanteric diameter $(\mathrm{cm})$ & $32.54 \pm 2.23$ & $(29-44)$ \\
Intertuberous diameter $(\mathrm{cm})$ & $12.41 \pm 1.51$ & $(10-21)$ \\
Baudelocque $(\mathrm{cm})$ & $20.40 \pm 1.62$ & $(12-24)$ \\
\hline
\end{tabular}

The results from this investigation reveal that the anthropometric measurements taken from young adult women, have shown a correlation with BMI and stature. The Pearson correlation coefficient between external pelvic parameters and stature, weight, BMI, and menarche age are shown in Table 2. The highest correlation coefficients between stature and IT, IC and for Baudelocque were $\mathrm{r}=0.580, \quad \mathrm{r}=0.504$ and $\mathrm{r}=0.502$, respectively $(\mathrm{p}=0.001)$. Moreover, the IT diameter has shown the highest correlation with body weight $(\mathrm{r}=0.749)$.
The correlation coefficient between IC, IS parameters and BMI were $\mathrm{r}=0.434$ and $\mathrm{r}=0.285$ $(\mathrm{p}<0.05)$. There was no statistically significant correlation coefficient between the BMI and ITb parameters $(\mathrm{r}=0.051 \mathrm{p}=0.649)$ and $(\mathrm{p}>0.05)$.

A negative correlation coefficient was obtained between menarche age and the IT diameter $(\mathrm{p}<0.05)$. However, a very low correlation has been determined between menarche age and the ITb diameter.

Table 2. The Pearson Correlation Coefficient between External Pelvic Parameters and Height, Weight, Body Mass Index, and Menarche Age

\begin{tabular}{lllll} 
Variables & Height & Weight & BMI & Menarche Age \\
\hline IC & $0.504^{*}$ & $0.662^{*}$ & $0.434^{*}$ & -0.072 \\
IS & $0.380^{*}$ & $0.464^{*}$ & $0.285^{*}$ & -0.113 \\
IT & $0.405^{*}$ & $0.749^{*}$ & $0.580^{*}$ & $-0.285^{*}$ \\
ITb & 0.096 & 0.097 & 0.051 & $0.223^{*}$ \\
Baudelocque & $0.322^{*}$ & $0.623^{*}$ & $0.502^{*}$ & -0.089 \\
\hline
\end{tabular}
*p $<0.05$.

Abbreviations: $\quad$ BMI=body mass index; IC=Intercrestal diameter; IS=Interspinous diameter; IT=Intertrochanteric diameter; $\mathrm{ITb}=$ Intertuberous diameter

The correlation graph between the intertrochanteric diameter (IT) and BMI is shown in Figure 3.



Figure 3. Correlation Graph between Intertrochanteric Diameter (IT) and BMI

\section{DISCUSSION}

The mean values of BMI, IC, IS, IT, ITb and Baudelocque diameter of participants were $22.71 \pm$ $3.26,27.88 \pm 1.74,25.31 \pm 2.01,32.54 \pm 2.23$, $12.41 \pm 1.51$, and $20.40 \pm 1.62$, respectively. BMI showed a strong correlation $(\mathrm{p}<0.05)$ between the other anthropometric variables. Significant positive correlations were found between IC and BMI $(\mathrm{r}=0.434)$, IS and BMI $(\mathrm{r}=0.285)$, IT and BMI $(\mathrm{r}=0.051)$, and Baudelocque diameter and BMI $(\mathrm{r}=0.502)$. No significant differences were found between ITb and BMI $(r=0.051$ and $p>0.05)$.

In the literature, anthropometric measurements were taken mostly from pregnant women. In our current study, measurements were taken from young non-pregnant adult women and this is the strength of our study. The fact that the 
measurements were taken from a small group is the limitation of this study.

The intertrochanteric diameter is the best indicator of head-pelvis incompatibility. It extends between the opposed trochanter major of the thigh bones and is $32 \mathrm{~cm}$ in the normal pelvis of a woman. In this study, the mean value of the IT was $32.54 \pm 2.23 \mathrm{~cm}$ (Table 1). In a study including Croatian perinatal women during a 25 -year period, this value was $31.83 \pm 1.96 \mathrm{~cm} .{ }^{4}$ According to their study, it has been reported that the intertrochanteric diameter has increased over time, with the largest amount of growth between the 1992-1994 period and the present. In African women, the mean value of IT was estimated to be $32 \pm 3.6 \mathrm{~cm}$ in a normal birth group and $29 \pm 3 \mathrm{~cm}$ in a cephalopelvic disproportion group, respectively. ${ }^{12}$ However, in a study done by Rozenholc et al., this value was $25.01 \pm 2.9 \mathrm{~cm}$ in a normal birth group and $23.9 \pm$ $2.9 \mathrm{~cm}$ in a dystocia group. ${ }^{16}$ According to these numbers, there are different mean values between the findings of Rozenholc and his colleagues and our results. In addition, studies by Liselele and Rozenholc have not observed similar results to each other, despite their participants being in similar regions. ${ }^{12,4}$

The highest point between both sides of the crista iliaca is $28 \mathrm{~cm}$ for external diameters in the normal pelvis of a typical woman. In this study, the IC mean value was $27.88 \pm 1.74 \mathrm{~cm}$ (Table 1 ). In a study that included Croatian perinatal women, this value was $27.79 \pm 1.56 \mathrm{~cm}$, and was found to increase between the 1992-1994 period and the present. ${ }^{4}$ Morever, Benjamin et al. reported an IC mean value of $27.2 \pm 1.9 \mathrm{~cm}$ in the normal delivery group and $26.9 \pm 2.6 \mathrm{~cm}$ in the caesarean delivery group, respectively. ${ }^{17}$

The IS diameter is $24 \mathrm{~cm}$ in a typical woman and extends between the two spina-anterior superior in a normal pelvis. In this study, the IS mean value was $25.31 \pm 2.01 \mathrm{~cm}$. According to a study by Vranes and Rados (4), this value was found to be $24.93 \pm 1.37 \mathrm{~cm}$. However, while in our study the sample consisted of young adult individuals with a mean age of 19 who were not pregnant, the study of Vranes and Rados was composed of parturient women with a mean age of 27 years. The values of the two studies are similar, despite the fact that the study of Vranes and Rados contained different physical, genetic, environmental, and cultural factors. ${ }^{4}$

Baudelocque diameter is the only external parameter associated with pelvic anterior-posterior distance. This is the distance between the spine of the fifth lumbar vertebra and the anterior aspect of the symphysis pubis; it is approximately $20 \mathrm{~cm}$ in the typical woman. In our present study, the Baudelocque mean value was found to be $20.40 \pm$ $1.62 \mathrm{~cm}$ (Table 1). According to Liselele's study, the mean value was $21.8 \pm 2.8$ for the normal birth group and $20.6 \pm 2.2 \mathrm{~cm}$ for the cephalopelvic disproportion group, respectively. ${ }^{12}$ It is interesting to note that the length of the Baudelocque measurement of young adults who have never given birth in our study is similar to women who have given birth before. These findings are similar and supported the previous study.

The intertuberous diameter is not related to cephalopelvic disproportion, however, this distance is often associated with outlet dystocia. In our study, the ITb mean value was found to be $12.41 \pm$ $1.51 \mathrm{~cm}$ (Table 1). Statistically significant relationships were not found between ITb and height, weight, or BMI. In the studies of Liselele and Rozenholc, the predictive value of $\mathrm{ITb}$ was determined by evaluating cephalopelvic disproportion. ${ }^{12,16}$ As the size of pelvis in women had significantly enlarged over the 25 -year period, we think that it is necessary to carry out further studies on this parameter because it is ITb values that are generally used for defining outlet dystocia. ${ }^{4}$ In order to see if the degree of correlation between weight and IT, IC, IS, and Baudelocque diameters in pregnant women is similar to that observed in pre-pregnant young adult women.

In our results, the IT diameter had the highest correlation with weight $(\mathrm{r}=0.749)$, while the Pearson correlation coefficient with BMI was $\mathrm{r}=0.580$ (Graph 1 and Table 2). Among studies done in pregnant women, Vranes and Rados examined the relationship of IT diameter with weight and BMI. ${ }^{4}$ They found a positive correlation between IT diameter and weight and BMI. The maximum correlation coefficient observed was $r=0.50$ for weight and $r=0.40$ for BMI. In the light of these data, it could be said that the pelvic anatomic shape width is close the other populations.

When we analyzed the correlations of the anthropometric indices, the IC correlations between weight and BMI were $r=0.662$ and $r=0.434$, respectively (Table 2). Whereas Vraneš and Radoš reported that the same correlations were $r=0.46$ for weight and $\mathrm{r}=0.35$ for $\mathrm{BMI} .{ }^{4}$ Also, in this paper a weak positive correlation between IS and BMI was observed at $\mathrm{r}=0.285$ and $\mathrm{p}=0.009$ (Tables 1 and 2 ). This can be compared to the correlation $\mathrm{r}=0.260$ in the study of. ${ }^{4}$

Baudelocque diameter is the only external parameter associated with pelvic anterior-posterior distance. In this study, the Baudelocque mean value was found to be $20.40 \pm 1.62 \mathrm{~cm}$ and showed the 
highest correlation with weight of any measurement $(\mathrm{r}=0.623, \mathrm{p}<0,05)$ (Tables 1 and 2$)$. According to Liselele's study, the Baudelocque mean value for the normal birth group was $21.8 \pm$ 2.8 and $20.6 \pm 2.2 \mathrm{~cm}$ for the cephalopelvic disproportion group, respectively. Our findings are similar to and therefore support the study by Liselele et al. ${ }^{12}$

\section{CONCLUSION}

In conclusion, we think that precise knowledge of how anthropometric indices in healthy adults correlate with cephalopelvic disproportion can be essential for determining maternal-fetal health. This knowledge can provide reference data, and can be used as reference values for evaluating the pelvis sizes of young Turkish women. We believe that in regions where it is difficult to access health services and where there are no adequate assessment tools, predicting pelvic sufficiency before birth is very important for maternal-fetal health. For this reason, in the absence of other sophisticated methods, external pelvimetry can be safely used to evaluate pelvic capacity. Furthermore, more quantitative data could be obtained using digital modeling methods in areas where these possibilities are convenient and future studies are needed.

\section{ACKNOWLEDGEMENTS}

The authors wish to thank the students of the Department of Midwifery and the faculty of the Health Sciences Department at Çukurova University.

\section{REFERENCES}

1. Standring S. Gray's anatomy: the anatomical basis of clinical practice. In: Tubbs RS, ed. Pelvic girdle and lower limb. Elsevier, 2016:1316.

2. Gabbe SG, Niebyl JR, Simpson JL, Landon MB, Galan HL, Jauniaux ER, et al. Obstetrics normal and problem pregnancies. In: Kilpatrick S, Garrison E, ed. Intrapartum care. 7th ed. Philadelphia: Elsevier, 2017:251.

3. DeSilva JM, Rosenberg KR. Anatomy, development, and function of the human pelvis. Anat Rec 2017;300:628-632.

4. Vraněs HS, Radoš SN. Secular changes of pelvis in Croatian perinatal women. HOMO 2014:65(6), 509-515.

5. Sharma K, Gupta P, Shandilya S. Age related changes in pelvis size among adolescent and adult females with reference to parturition from Naraingarh, Haryana (India). HOMO 2016;67(4): 273-293.
6. Munabi IG, Byamugisha J, Luboobi L, Luboga SA, Mirembe F. Relationship between maternal pelvis height and other anthropometric measurements in a multisite cohort of Ugandan mothers. Pan African Medical Journal 2016a;24:257.

7. Munabi IG, Luboga SA, Luboobi L, Mirembe F. Association between maternal pelvis height and intrapartum foetal head moulding in Ugandan mothers with spontaneous vertex deliveries. Obstet Gynecol Int 2016b.

8. Sule ST, Matawal BI. Antenatal clinical pelvimetry in primigravidae and outcome of labour. Ann Afr Med 2005;4:164-167.

9. Awonuga AO, Merhi Z, Awonuga MT, Samuels TA, Waller J, Pring D. Anthropometric measurements in the diagnosis of pelvic size: an analysis of maternal height and shoe size and computed tomography pelvimetric data. Arch Gynecol Obstet 2007;276:523-528.

10. Dujardin B, Cutsem RV, Lambrechts T. The value of maternal height as a risk factor of dystocia: a meta-analysis. Trop Med Int Health 1996;1:510-521.

11. Van Bogaert LJ. The relation between height, foot length, pelvic adequacy and mode of delivery. Eur J Obstet Gynecol Reprod Biol 1999;82:195-199.

12. Liselele $\mathrm{HB}$, Boulvain $\mathrm{M}$, Tshibangu $\mathrm{KC}$, Meuris S. Maternal height and external pelvimetry to predict cephalopelvic disproportion in nulliparous African women: a cohort study. Br J Obstet Gynaecol 2000;107:947-952.

13. Chan Ben CP, Lao Terence TH. The impact of maternal height on intrapartum operative delivery: a reappraisal. J Obstet Gynaecol Res 2009;35:307-314.

14. Alijahan R, Kordi M, Poorjavad M, Ebrahimzadeh S. Diagnostic accuracy of maternal anthropometric measurements as predictors for dystocia in nulliparous women. Iran J Nurs Midwifery Res 2014;19:11.

15. Hambidge KM, Krebs NF, Garcés A, Westcott JE, Figueroa L, Goudar SS et al. Anthropometric indices for non-pregnant women of childbearing age differ widely among four low-middle income populations. BMC Public Health 2018;18:45.

16. Rozenholc AT, Ako SN, Leke RJ, Boulvain M. The diagnostic accuracy of external pelvimetry and maternal height to predict dystocia in nulliparous women: a study in Cameroon. Br J Obstet Gynaecol 2007;114:630-635.

17. Benjamin SJ, Daniel AB, Kamath A, Ramkumar V. Anthropometric measurements as predictors of cephalopelvic disproportion. Acta Obstet Gynecol Scand 2012; 91:122-127. 